\title{
Management of marginality with approach to the empowerment in Mashhad
}

\author{
Sara Hosseinzadehl \\ Katayoon AlizadehII \\ Hamid JafarillI
}

\begin{abstract}
In this paper, the reasons for marginal growth in Mashhad were examined. Marginalization in the areas around the city was reviewed and the margin management in the direction of empowerment was evaluated. The main goal is to find solutions for better management of marginalized areas based on empowerment approach. Research method is descriptive-analytic and data are obtained through documentary and field studies (completed questionnaires). In order to test the research hypotheses, statistical analysis of factor analysis, analysis of variance, Spearman correlation coefficient and Mann-Whitney test have been used. The statistical population consists of 922282 people in eight marginal areas of Mashhad that includes 66 marginal neighborhoods. From statistical population, 400 people were selected as samples. To obtain sample size, the Cochran formula has been used with a $95 \%$ confidence interval and a standard error of $5 \%$. The research findings show that the best solution for better management of the marginalized areas is the economic empowerment of the marginalized population, which, of course, has been implemented for empowerment. In the field and practical part, 384 randomly selected questionnaires were completed by residents of marginal neighborhoods of Mashhad. Finally, in the analytical section, the information obtained in the above steps was analyzed using the SPSS software program.
\end{abstract}

Keywords: Economic empowerment; Informal settlements; Marginalization; Management; Mashhad

I Ph.D. Student of Geography and Urban Planning, Mashhad Branch, Islamic Azad University, Mashhad, Iran Sara.hoseynzadeh68@gmail.com

II Assistant Professor, Department of Geography and Urban Planning, Mashhad Branch, Islamic Azad University, Mashhad, Iran - katayoon_alizadeh@yahoo.com

IIIAssistant Professor, Department of Geography, Mashhad Branch, Islamic Azad university, Mashhad, Iran hamidjafari@yahoo.com 


\section{Introduction}

Poor households spend a large part of their income instead of housing on basic needs such as food, education and health. Therefore, theyS live in informal settlements that provide the poor with affordable options. Millions of poor families are unable to afford housing because of housing and financial constraints (UN-Habitat, 2011).In Asia, 30\% of the urban population lives in these settlements (UN-Habitat, 2013). This phenomenon has been generalized over the past six decades to the major cities in Iran, including families and people living in rural areas adjacent to urban areas.

Informal settlements are residential areas where: 1) Residents of any kind are instable on the land or housing they inhabit, in any circumstances, they have a instable residence on the land or house in which they reside; 2) Local neighborhoods usually do not have basic services and urban infrastructure and 3) Settlements may not be compatible with current planning and building regulations and are often at high risk areas of geography and environment (UN-Habitat, 2013). population, with about $28 \%$ of the total population being marginalized since the 1980s, and this ratio has not diminished (Mirei et al., 2012). Discontinuity of spatial and social structure of Mashhad city in the wake of unbridled accelerated urbanization in the recent decades is clear. This imposes serious consequences to the Mashhad city body. These factors led to the accumulation of the asymmetrical urban population in the case study region. The formation of informal settlements, with abnormal tissue and nonstandard text leads to inefficient of urban projects and as a result urban health system is facing with serious challenges. Massive volume of 1.2 million marginalized peoples in the study area makes it necessary to political and municipal authorities to pay more attention to the crisis and the demands of citizens. Therefore, they have to make purposeful decisions to empower urban residents and secure equilibrium that are important issues (Nucci, 2016).

Empowerment view is still ongoing and is increasing across the world (Cook and Ruming, 2008). Social capital should be considered as one of the factors influencing the empowerment of societies due to its wide range of capabilities in that, in turn, this 
empowerment in its turn focuses on raising the quality of life by creating favorable conditions in different fields (Khanh, 2011).

With regard to urban marginalization and how to deal with the phenomenon of marginalization, many views have been mentioned: In cities of Iran, solutions such as the removal, destruction, or the provision of services by related organizations have been used without the citizenship right and the use of the participatory force of these communities, none of which has been solved, therefore, it is necessary to seek a fundamental solution which is based on the way of dealing with these types of settlements, so that it could establish a two-way interaction with localities in the context of the city. Organizing and empowering them is the most effective and best suited to global experiences.

\section{Methodology}

The marginalization has created a lot of problems for the city of Mashhad. The need for research on the marginalization risks and the importance of the management of empowerment of marginalized people can be helpful in reducing these risks. In our studies, we seek to answer questions as well as plans. There are assumptions that we will look at in more detail. The issues raised in the research were: What is more important than other indicators of empowerment in the marginal areas of Mashhad and if it is possible to shift the margin and marginalization towards economic empowerment and discussion on the rate of success for executive programs for economic empowerment of marginalized inhabitants in Mashhad. Our hypotheses to investigate the problem of nocturnal margin in order to meet the above questions were:

- Economic empowerment is the most important indicator in the management of marginalized areas.

- Vocational training courses have been effective in helping the household managers in marginal areas.

- Economic empowerment programs that have been implemented have not had much success or impact. 
The present study tries to provide an overview of the sources and documents of existing studies and case study of marginal areas of Mashhad by finally answering the questions and hypotheses of a coherent general approach on marginalization management with the empowerment approach in the city.

In this paper, the reasons for marginal growth in Mashhad were examined. Marginalization in the areas around the city was reviewed and the margin management in the direction of empowerment was evaluated. The main goal is to find solutions for better management of marginalized areas based on empowerment approach. Research method is descriptive-analytic and data are obtained through documentary and field studies (completed questionnaires). In order to test the research hypotheses, statistical analysis of factor analysis, analysis of variance, Spearman correlation coefficient and Mann-Whitney test have been used. The statistical population consists of 922282 people in eight marginal areas of Mashhad that includes 66 marginal neighborhoods. From statistical population, 400 people were selected as samples. To obtain sample size, the Cochran formula has been used with a $95 \%$ confidence interval and a standard error of $5 \%$. The research findings show that the best solution for better management of the marginalized areas is the economic empowerment of the marginalized population, which, of course, has been implemented for empowerment. In the field and practical part, 384 randomly selected questionnaires were completed by residents of marginal neighborhoods of Mashhad. Finally, in the analytical section, the information obtained in the above steps was analyzed using the SPSS software program.

\section{Results}

According to the municipality of Mashhad in 2016, this city has 66 marginal zones. Of these 66 zones, 10 neighborhoods in seven zones were selected in different geographical directions for study. Factors such as the geographical location of marginal neighborhoods, ethnic status, and the origin of immigration have also been taken into consideration. From the old road of Quchan, the neighborhoods of Imam Ali and Kal Zarkesh settlements, from the Cisabad area of the Syasabad district, from the Khajerabi area to Khajerabi 
neighborhood, from the al-Taimour district of Dish-Dish area and Fatemiyeh area, from the area of the Daruy neighborhood of Daraw, from the Golshahr area of Golshahr district And RohAbad, from the Seyedi neighborhood of Quiyem and Kooy Vali Asr neighborhood, were selected from the galesakhtiman neighborhood building (Mashhad Municipality, 2016).

\subsection{The demographic features of the Mashhad's informal settlements}

Population density in the area of informal settlements in Mashhad is 231 people per hectare, which is a sign of a high density of population in this area. This feature is shown in Figure 1.

Fig 1 - Diagram (1) Population Density of Approved Zones in the Area of Informal Settlements (N / A) 2016

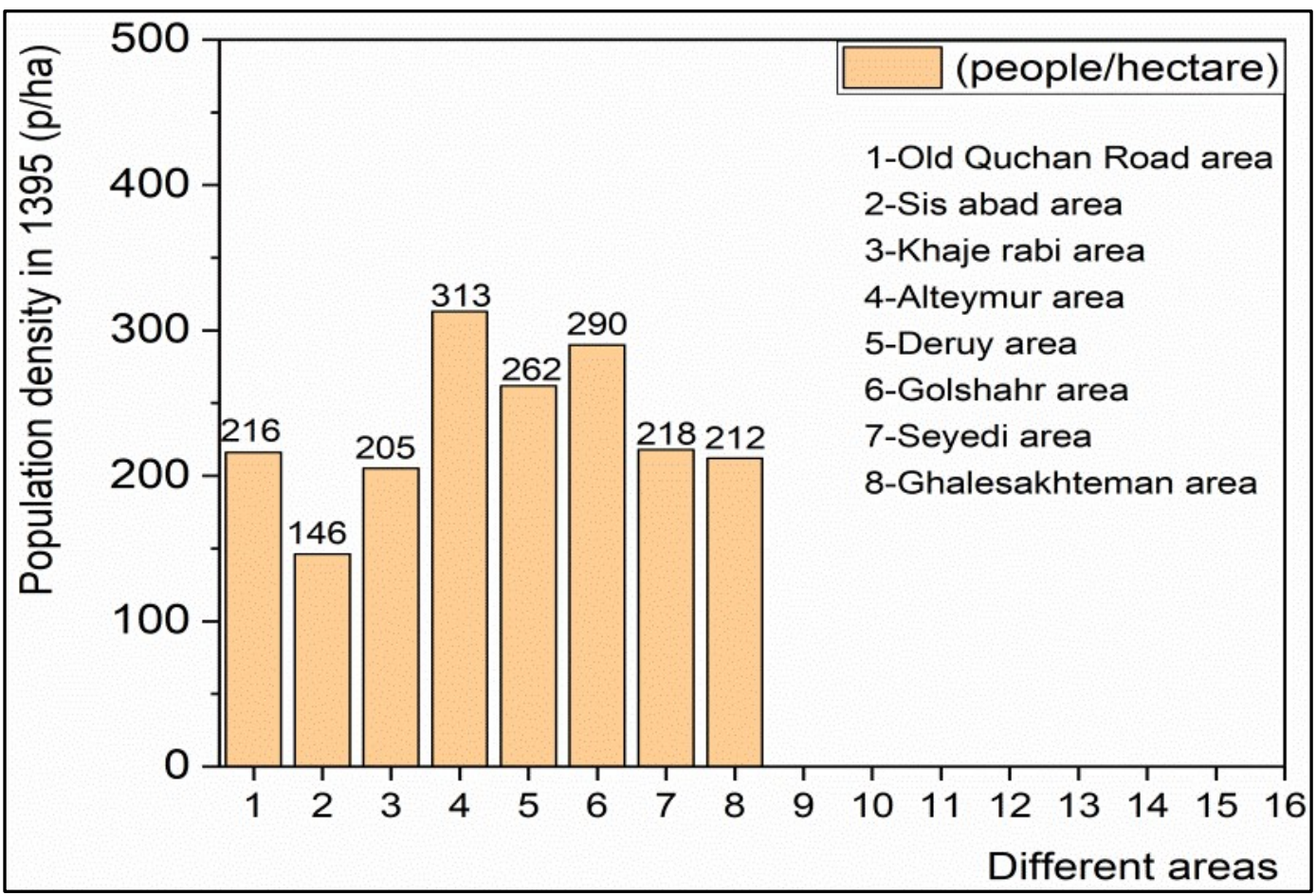

\subsection{The results of the first hypothesis:}

Empowerment programs that have been implemented so far have not achieved significant economic success. The hypotheses examined are as follows:

$$
\begin{aligned}
& \mu_{0}: \mu=0 \\
& \mu_{0}: \mu \neq 0
\end{aligned}
$$


In equation (1), $\mu_{\text {is }}$ the average impact of empowerment on economic success in marginalized areas, that is, whether empowerment programs that have been implemented so far have made economic success in the marginalized regions.

The result of this test is presented as follows. This question has been analyzed using the binomial statistical test. Table 1 shows the Test for total research hypothesis.

Table 1 - Test the total research hypothesis

\begin{tabular}{|c|c|c|c|c|c|c|}
\hline & & Category & $\mathbf{N}$ & $\begin{array}{l}\text { Observed } \\
\text { Prop. }\end{array}$ & $\begin{array}{l}\text { Test } \\
\text { Prop. }\end{array}$ & $\begin{array}{l}\text { Asymp. } \\
\text { Sig. (2- } \\
\text { tailed) }\end{array}$ \\
\hline \multirow{3}{*}{$\begin{array}{l}\text { The amount } \\
\text { of government } \\
\text { investment to } \\
\text { create } \\
\text { employment for } \\
\text { men }\end{array}$} & $\begin{array}{r}\text { first } \\
\text { group }\end{array}$ & $<=3$ & 327 & .85 & .50 & \multirow[t]{3}{*}{$.000 a$} \\
\hline & $\begin{array}{l}\text { The } \\
\text { second } \\
\text { group }\end{array}$ & $>3$ & 57 & . 15 & 50 & \\
\hline & Total & & 384 & 1.00 & 50 & \\
\hline \multirow{3}{*}{$\begin{array}{l}\text { The amount } \\
\text { of government } \\
\text { investment to } \\
\text { create } \\
\text { employment for } \\
\text { men }\end{array}$} & $\begin{array}{r}\text { first } \\
\text { group }\end{array}$ & $<=3$ & 354 & .92 & .50 & \multirow[t]{3}{*}{$.000 a$} \\
\hline & $\begin{array}{l}\text { The } \\
\text { second } \\
\text { group }\end{array}$ & $>3$ & 30 & .08 & 50 & \\
\hline & Total & & 384 & 1.00 & 50 & \\
\hline \multirow{3}{*}{$\begin{array}{l}\text { Creating } \\
\text { employment for } \\
\text { men }\end{array}$} & $\begin{array}{l}\text { first } \\
\text { group }\end{array}$ & $<=3$ & 357 & .93 & .50 & \multirow[t]{3}{*}{$.000 a$} \\
\hline & $\begin{array}{l}\text { The } \\
\text { second } \\
\text { group }\end{array}$ & $>3$ & 27 & .07 & 50 & \\
\hline & Total & & 384 & 1.00 & 50 & \\
\hline \multirow{3}{*}{$\begin{array}{l}\text { Creating } \\
\text { employment for } \\
\text { women }\end{array}$} & $\begin{array}{c}\text { first } \\
\text { group }\end{array}$ & $<=3$ & 354 & .92 & .50 & \multirow[t]{3}{*}{$.000 a$} \\
\hline & $\begin{array}{l}\text { The } \\
\text { second } \\
\text { group }\end{array}$ & $>3$ & 30 & .08 & 50 & \\
\hline & Total & & 384 & 1.00 & 50 & \\
\hline \multirow{2}{*}{$\begin{array}{l}\text { The amount } \\
\text { of access to a } \\
\text { suitable job }\end{array}$} & $\begin{array}{r}\text { first } \\
\text { group }\end{array}$ & $<=3$ & 363 & .95 & .50 & \multirow[t]{2}{*}{$.000 a$} \\
\hline & $\begin{array}{l}\text { The } \\
\text { second } \\
\text { group }\end{array}$ & $>3$ & 21 & .05 & 50 & \\
\hline
\end{tabular}




\begin{tabular}{|c|c|c|c|c|c|c|}
\hline & Total & & 384 & 1.00 & 50 & \\
\hline \multirow{3}{*}{$\begin{array}{l}\quad \text { Provide } \\
\text { grounds for } \\
\text { men's } \\
\text { employment }\end{array}$} & $\begin{array}{l}\text { first } \\
\text { group }\end{array}$ & $<=3$ & 346 & .90 & .50 & \multirow[t]{3}{*}{.000} \\
\hline & $\begin{array}{l}\text { The } \\
\text { second } \\
\text { group }\end{array}$ & $>3$ & 38 & .10 & 50 & \\
\hline & Total & & 384 & 1.00 & 50 & \\
\hline \multirow{3}{*}{$\begin{array}{l}\text { Women's } \\
\text { employment }\end{array}$} & $\begin{array}{l}\text { first } \\
\text { group }\end{array}$ & $<=3$ & 299 & .78 & .50 & \multirow[t]{3}{*}{$.000 a$} \\
\hline & $\begin{array}{l}\text { The } \\
\text { second } \\
\text { group }\end{array}$ & $>3$ & 85 & .22 & 50 & \\
\hline & Total & & 384 & 1.00 & 50 & \\
\hline
\end{tabular}

According to Table 1 , since the criterion of the decision reached at the output $(000)$ is less than 05 , one cannot rule out the zero hypothesis, that is, the economic empowerment of the marginalized people has affected this community. The ratio of success less than $50 \%$ of the tested proportion is greater than the actual value, i.e., the proportion of those who fail to respond is much higher.

But analyzes indicate that empowerment can play an effective role in the economic independence of individuals in these regions. As the percentage is $\geq 0$, we conclude that there is a relationship between the index of economic independence and empowerment.

\subsection{The results of the second hypothesis:}

Economic empowerment is the most important factor in the management of marginalized areas. In order to confirm or reject the second hypothesis using equation (1), the role of empowerment in marginalized management with regard to two variables, Spearman correlation coefficient was selected as a statistical test. Table 2 shows the marginal Empowerment Management Index.

Table 2 - Marginal Empowerment Management Index

\begin{tabular}{r|c|c}
\hline Sig & Management & Empowerment \\
\hline 000. & 0.847 & 0.847 \\
\hline
\end{tabular}


The findings of Table (6) show that the economic empowerment of the inhabitants of these neighborhoods can play a fundamental role in the management of marginalized areas, meaning that there is a significant relationship between management and empowerment. So, it can be concluded that the second hypothesis is approved.

\subsection{The results of the third hypothesis:}

Investigating whether effective vocational training courses have helped to improve the economic empowerment of family caretakers in marginalized areas. In order to confirm or reject the third hypothesis we used equation (1). Table 3 shows the relationship between technical and vocational skills with the empowerment of marginalized people.

Table 3 - The relationship between technical and vocational skills with the empowerment of marginalized people

\begin{tabular}{l|c|c|c}
\hline \multicolumn{1}{c|}{ Independent variable } & $\begin{array}{c}\text { The dependent } \\
\text { variable }\end{array}$ & $\begin{array}{c}\text { Spearman } \\
\text { correlation } \\
\text { coefficient }\end{array}$ & $\begin{array}{c}\text { Significant } \\
\text { level }\end{array}$ \\
\cline { 1 - 3 } $\begin{array}{l}\text { Technical and vocational } \\
\text { courses }\end{array}$ & $\begin{array}{c}\text { Empowerment } \\
\text { Technical skills }\end{array}$ & -.047 & $\begin{array}{c}\text { There is a } \\
\text { meaningful } \\
\text { relationship }\end{array}$ \\
\hline
\end{tabular}

Spearman's correlation coefficient between variables of technical skills and vocational training and empowerment is equal to 0.477 , which is significant at level 0.356 . Therefore, the hypothesis of the existence of the relationship between technical and vocational skills in empowerment of the marginal areas of the city is confirmed. Table 4 shows the economic empowerment of people living in marginalized areas.

Table 4 - Economic empowerment of people living in marginalized areas

\begin{tabular}{c|c|c|c}
\hline Component & $\begin{array}{c}\text { Spearman } \\
\text { correlation } \\
\text { coefficient }\end{array}$ & $\begin{array}{c}\text { Significant } \\
\text { level }\end{array}$ & Test result \\
\hline Granting microcredit & 160,0 & 0.002 & Meaningful \\
\hline
\end{tabular}




\begin{tabular}{l|c|c|c}
\hline $\begin{array}{l}\text { Technical and } \\
\text { vocational training for } \\
\text { literacy }\end{array}$ & 160,0 & 0.002 & Meaningful \\
\hline $\begin{array}{l}\text { Attracting investment } \\
\text { from other areas }\end{array}$ & -.020 & 0.695 & Meaningful \\
\hline $\begin{array}{l}\text { Attracting Charity } \\
\text { Contributions }\end{array}$ & 0.041 & 0.428 & Meaningful \\
\hline $\begin{array}{l}\text { Facilitate access to } \\
\text { work centers }\end{array}$ & 0.037 & 0.475 & Meaningful \\
\hline $\begin{array}{l}\text { Establishing } \\
\text { marketing institutions }\end{array}$ & 0.107 & 0.036 & Meaningful \\
\hline
\end{tabular}

Considering the fact that significance level in the Spearman test is between -1 and 1 , obtained result means that the components in the table above can play a significant role in the empowerment of men, and the result of this test has a significant relationship. Table 5 shows the Mann-Whitney test for the success rate of programs implemented in the field of empowerment

Table 5 - Mann-Whitney test for the success rate of programs implemented in the field of empowerment

\begin{tabular}{c|c}
\hline \multicolumn{1}{c|}{ Amount of $\mathbf{Z}$} & - \\
1.076 \\
\hline $\begin{array}{c}\text { The significance } \\
\text { level }\end{array}$ & 0.282 \\
\hline
\end{tabular}

According to Table 5, a meaningful value of 0.282 was found to be greater than 0.05 , so there is no significant difference between the success rate of programs implemented in the field of empowerment in these neighborhoods. Table 6 shows the investigations related to the extent of urban management proceedings for the empowerment of marginalized inhabitants. 
Table 6 - Investigating the extent of urban management proceedings for the empowerment of marginalized inhabitants

\begin{tabular}{l|c|c|c}
\hline \multicolumn{1}{c|}{ Component } & $\begin{array}{c}\text { Significance } \\
\text { factor sig** }\end{array}$ & $\begin{array}{c}\text { Chi-square } \\
\text { coefficient }\end{array}$ & $\begin{array}{c}\text { Degrees of } \\
\text { freedom }\end{array}$ \\
\hline $\begin{array}{l}\text { Provide employment opportunities } \\
\text { for men }\end{array}$ & .000 & 178.969 & 4 \\
\hline $\begin{array}{l}\text { Provide employment opportunities } \\
\text { for women }\end{array}$ & .000 & 73.891 & 4 \\
\hline $\begin{array}{l}\text { The amount of access to a suitable } \\
\text { job }\end{array}$ & .000 & 317.849 & 4 \\
\hline $\begin{array}{l}\text { The role of government in creating } \\
\text { employment for men }\end{array}$ & .000 & 484.411 & 4 \\
\hline $\begin{array}{l}\text { The role of government in creating } \\
\text { employment for women }\end{array}$ & .000 & 434.255 & 4 \\
\hline $\begin{array}{l}\text { The amount of public sector } \\
\text { investment in creating employment } \\
\text { for men }\end{array}$ & .000 & 500.036 & 4 \\
\hline $\begin{array}{l}\text { The amount of investment in } \\
\text { creating employment for women }\end{array}$ & .000 & 424.620 & 4 \\
\hline
\end{tabular}

The information contained in table 6 shows that most of the proceedings taken by urban management for the economic potential of marginalized areas are located in the low and very low region; in fact, urban management has not been able to make the necessary arrangements in terms of employment regulation. Table 7 shows the amount of initial subscription and subsequent factorization for the variables entered in the factor analysis.

Table 7: The amount of initial subscription and subsequent factorization for the variables entered in the factor analysis

\begin{tabular}{l|l|l}
\hline & Initial & Extraction \\
\hline J lending & 1,000 & 0.684 \\
\hline ical training & 1,000 & 0.290 \\
\hline tment attraction & 1,000 & 0.361 \\
\hline
\end{tabular}




\begin{tabular}{l|l|l}
\hline ct Participation & 1,000 & 0.520 \\
\hline tate access to work centers & 1,000 & 0.427 \\
\hline lishing marketing institutions & 1,000 & 0.625 \\
\hline
\end{tabular}

Today, the main obstacle to many of the strategies for dealing with informal settlements is to ignore them as a local community with widespread networks of trust and normalization that can bring their own assets with the support of the government and facilitator, and the dilemma Solve itself with communicative action.

\section{Discussion}

The results show that the analysis of this approach considers poverty and staying in marginal areas as a structural phenomenon which is reproduced frequently and local actions only reduces for a temporal time. Among them, there are many factors and barriers involved that can be overcome in a long process with the active participation of interest groups. Thus, the residents' activities focused on empowering neighborhood have a key role and if it is possible to provide better distribution of resources based on the needs of residents, the sustainability of development in the neighborhood will be ensured. Considering the prioritization of the needs of the residents of informal settlements in Mashhad, it seems that the following policies and strategies are effective for the empowerment of the community.

Participation of residents in implementing neighborhood empowerment projects and involving more government agencies and organizations in the neighborhood in order to create jobs. The government can work with privatization and development, while preventing many of the effects of long-term unemployment, with a decreasing presence of unemployed members in a family which reduces marginalization. Similarly, the use of the potential and resources of the private sector for investment and the creation of workshops of production and reviewing how to formulate and implement the laws of urban land in the city in order 
to prevent the use of profitable individuals in the field of land sales and land use, can have an effective role in reducing marginalization problems in Mashhad.

Informal settlements are one of the symbols of urban poverty that is located in or adjacent to urban areas (especially in large cities) and is self-organized, without a formal building, and urban planning permits by low-income groups, created with a very low quality and quantity for life. Studies have shown that informal settlements have become one of the most important issues in urban areas in Indonesia (Alzamil, 2018). The emergence of informal settlements has a lot of reputation in Jakarta and has become more serious in recent decades.

In reference Wokekoro (2017), showed that a large percentage of residents of two informal neighborhoods in Harcourt Port's neighborhood qualitative indicators such as neighborhood cleanliness, life and property safety, residential planning, housing provision for the poor, hospitals / clinics, recreation areas, public schools, the maintenance of streets and fire stations is inadequate.

As the economic, social and environmental impacts of climate change become increasingly apparent in the Philippines, community-based approaches to disaster risk reduction and management (DRRM) have become the new orthodoxy, framed by narratives of participation, empowerment and resilience (Ramalho, 2018).

in informal settlements, in addition to enhancing the legal dimension of seizure, with tools such as the implementation of civil-law cadastre and the consolidation of ownership and documentation of seizure, it should strengthen and increase the conventional and perceptual dimensions of security of seizure by measures such as increasing Sense of belonging to the environment and promoting the quality of urban, educational and social services (Ghoreyshi Madineh et al., 2018).

\section{Conclusion}

Reasons for marginal growth in Mashhad were examined. Marginalization in the areas around the city was reviewed and the margin management in the direction of empowerment was evaluated. The main goal was to find solutions for better management of marginalized 
areas based on empowerment approach. Research method performed in descriptiveanalytic way and data are obtained through documentary and field studies (completed questionnaires). In order to test the research hypotheses, statistical analysis of factor analysis, analysis of variance, Spearman correlation coefficient and Mann-Whitney test have been used. To obtain sample size, the Cochran formula has been used with a $95 \%$ confidence interval and a standard error of $5 \%$. The research findings show that the best solution for better management of the marginalized areas is the economic empowerment of the marginalized population. In the field and practical part, 384 randomly selected questionnaires were completed by residents of marginal neighborhoods of Mashhad. In the analytical section, the information obtained in the above steps was analyzed using the SPSS software program.

\section{References}

Cook, N and Ruming, K. J. (2008). On the Fringe of Neoliberalism: Service and Infrastructure Provision in Residential Development in Sydney, Australian 11- Geographer, 39(2), 211-228.

Ghoreyshi Madineh seyyed sajad, Ramatullah Farhoudi, Hasan Roosta. (2018). Analysis of the Role of Cadastre in Empowerment of Informal Settlements (Case Study: Ahvaz City), Fundamental Research in Electrical Engineering, 12(4), 941-955.

Khanh, Ho Le Phi. (2011). The Role of Social Capital to Access Rural Credit: Acase study at Dinh Cu and Van Quat Dong village in coastal of Thua Thien Hue province- Vietnam. Journal of Development Economics, 81(1), 213-235.

Mashhad Municipality. (2016). Statistical Yearbook of Mashhad, Mashhad Municipality Publications, deputy of planning and development, SAMT publication.

Mirei, M., Hatami Nejad, H. \& Khodayi, Z. (2012). Informal Settlement in the World and Iran, ACECR Publisher of Alborz Province.

Nucci Lucia. (2016). Analysis the Process and Priorities of Urbanization in the Mashhad city After Islamic Revolution of Iran, International journal of humanities and cultural studies, 3(3), 67-88.

Ramalho Jordana. (2019). Empowerment in the era of resilience-building: gendered participation in community-based (disaster) risk management in the Philippines. International Development Planning Review 41(2), 129-148. 
UN-Habitat. (2011). Affordable Land and Housing in Asia. Nairobi United Nations Human Settlements Programmed, Vol 2, 234-255.

UN-Habitat. (2013). State of the World's Cities 2012/2013: Prosperity of Cities. Taylor \& Francis publisher, 567-599.

UN-Habitat. (2013). The Challenge of Slums; UN---Habitat, The State of the World Cities Report 2012/13. Land for 'security of tenure' definition, 9, 334-366.

Waleed S, Alzamil. (2018). Evaluating Urban Status of Informal Settlements in Indonesia: A Comparative Analysis of Three Case Studies in North Jakarta. Journal of Sustainable Development, 11(4), 148-173. DOI:10.5539/jsd.v11n4p148

Wokekoro, Ebiwari. (2017). The Role of Environmental Factors in Nurturing Children's Creativity, Journal of Gardening, International Journal of Social Sciences and Humanities Invention, 4(1): 3192-3201 